\title{
Kinerja Keuangan terhadap Profitabilitas pada Perusahaan Pertambangan di Bursa Efek Indonesia
}

\author{
Ida Zuraidah ${ }^{1)}$, Rosalina Ghozali ${ }^{2)}$ \\ 1), 2) Program Studi Akuntansi, Fakultas Ekonomi dan Bisnis, Universitas Muhammadiyah Palembang \\ 1) id4.syoib@gmail.com, rosalinaghozali1@gmail.com $\left.{ }^{2}\right)$
}

\begin{abstract}
This study uses panel data, using multiple linear regression for statistical data processing. This study aims to analyze the effect of Working Capital Turnover (X1), Firm Size (X2), Liquidity (X3), Leverage (X4) on profitability $(\mathrm{Y})$ in mining companies on the Indonesia Stock Exchange (BEI) 2015-2019. Statistical calculations produce a regression equation $\mathrm{Y}=-0.006571+0.000812 \mathrm{X} 1-0.000143 \mathrm{X} 2+0.036545 \mathrm{X} 3$ $0.011253 \mathrm{X} 4+\mathrm{e}$. This study concludes first, Working Capital Turnover does not have a significant positive effect on profitability. Second, Firm Size does not have a significant negative effect on profitability. Third, liquidity has a significant positive effect on profitability. Fourth, Leverage does not have a significant positive effect on profitability of mining companies on the Indonesia Stock Exchange (IDX). Fifth, Working Capital Turnover, Firm Size, Liquidity, Leverage together, positively and significantly affect profitability (Y) in mining companies on the Indonesia Stock Exchange (IDX). The researcher gives the first suggestion, mining companies listed on the Indonesia Stock Exchange must maintain the stability of their financial performance, if necessary, increase their working capital, firm size, liquidity and leverage in order to maintain and increase the company's profitability. Second, shareholders of Mining Companies listed on the Indonesia Stock Exchange do not immediately withdraw their shares when the share price drops, because it is hoped that stability will not take too long and working capital, firm size, liquidity and leverage will increase again so that they can increase the company's profitability. and the stock price went up again.
\end{abstract}

Keywords: Working Capital, Firm Size, Liquidity, Leverage and Profitability.

\section{Pendahuluan}

Perusahaan bertujuan memperoleh laba seoptimal mungkin. Perolehana laba yang maksimal, maka perusahaan dapat mempertahankan kelangsungan hidupnya dan dapat terus berkembang serta memberikan pengembalian yang menguntungkan bagi pemiliknya. Persaingan yang terus meningkat pada saat ini, tujuan tersebut tidaklah mudah dicapai. Manajemen perusahaan dituntut untuk dapat mengelola sumber daya yang dimilikinya dengan lebih efektif dan efisien serta dapat menghasilkan keputusan yang menunjang terhadap pencapaian tujuan perusahaan. Laba atau profit perusahaan dapat diperoleh dengan memanfaatkan seluruh sumber daya yang ada dengan efektif dan efisien, baik itu perusahaan dagang, perusahaan jasa, maupun perusahaan manufaktur. Tanpa diperolehnya laba, perusahaan tidak dapat memenuhi tujuan lainnya yaitu berkembang (growth), bertahan hidup (going concern), dan tanggung jawab sosial (corporate social responsibility). Laba yang menjadi tujuan utama perusahaan dapat dicapai melalui penjualan barang dan jasa. Semakin tinggi penjualan maka laba yang dihasilkan perusahaan juga akan semakin besar. Kelangsungan hidup perusahaan (going concern) dipengaruhi oleh banyak hal, salah satunya adalah profitabilitas perusahaan itu sendiri.

Martono (2011:53) mengemukakan bahwa "profitabilitas adalah "Kemampuan perusahaan dalam memenuhi kewajiban-kewajiban finansialnya yang harus segera dipenuhi atau kewajiban jangka pendeknya." Profitabilitas adalah hasil akhir dari 
sejumlah kebijakan dan keputusan yang dilakukan oleh perusahaan. Dengan kata lain, profitabilitas adalah kemampuan suatu perusahaan untuk mencapai laba. Kegiatan operasional setiap perusahaan membutuhkan potensi sumber daya. Salah satunya adalah modal kerja. Abdullah (2005:71) mengemukakan bahwa "manajemen penggunaan modal kerja dapat diuji dengan menggunakan rasio perputaran modal kerja (working capital turnover), yakni perbandingan antara penjualan dengan jumlah keseluruhan aset lancar yang dimiliki suatu perusahaan pada suatu periode tertentu". Aktivitas operasional ini akan membuat adanya perputaran modal kerja yang terjadi di perusahaan.

Suwito dan Heraway (2005:218) mengemukakan bahwa firm size adalah "pengelompokan perusahaan kedalam beberapa kelompok, diantaranya perusahaan besar, sedang dan kecil. Skala perusahaaan merupakan ukuran yang dipakai untuk mencerminkan besar kecilnya perushaan yang didasarkan kepada total asset perusahaaan". Ukuran perusahaan (firm size) adalah skala besar kecilnya perusahaan, suatu perusahaan besar yang sudah mapan akan memiliki akses yang mudah menuju pasar modal.

Selain perputaran modal kerja, faktor lain yang harus diperhatikan oleh perusahaan adalah likuiditas. Sebagai perusahaan yang berorientasi pada laba, maka laba memiliki peranan yang sangat dominan untuk menentukan apakah perusahaan tersebut dapat terus bertahan didunia perindustrian. Salah satu cara agar perusahaan dapat mempertahankan serta memajukan perusahaannya yaitu dengan terus memantau tingkat likuiditas perusahaannya. Martono (2011:55) mengemukakan bahwa "likuiditas adalah "kemampuan perusahaan untuk membayar atau melunasi kewajiban-kewajiban finansialnya pada saat jatuh tempo dengan mempergunakan aset lancar yang tersedia".

Kinerja keuangan lainnya adalah leverage. Martono (2011:295) mengemukakan bahwa leverage adalah "penggunaan asset atau dana tersebut perushaan harus mengeluarkan biaya tetap atau beban tetap, dimaksudkan untuk meningkatkan keuntungan potensial bagi pemegang saham". Perusahaan yang memiliki tingkat leverage keuangan yang tinggi akan berakibat kesulitan dalam keuangan untuk bisa menyelesaikan kewajiban hutangnya. Dengan kata lain leverage keuangan memiliki dampak yang baik dan buruk bagi perusahaan. Dampak baiknya dapat menyebabkan perusahaan menjadi berkembang lebih baik (kinerja baik), dan dampak buruknya mengakibatkan kinerja perusahaan menjadi menurun bahkan dapat berakibat pada kondisi kepailitan atau bangkrut.

Debora (2014) yang menganalisis pengaruh likuiditas dan manajemen modal kerja terhadap profitabilitas perusahaan industri tekstil dan garmen yang terdaftar di Bursa Efek Indonesia Periode 2009-2012. Hasil pengujian menunjukkan bahwa secara parsial likuiditas berpengaruh terhadap profitabilitas, sedangkan perputaran modal kerja dan peputaran persediaan tidak berpengaruh signifikan terhadap profitabilitas. Namun secara simultan, likuiditas dan, perputaran modal kerja, dan perputaran persediaan tidak berpengaruh signifikan terhadap profitabilitas. Penelitian Ginting (2013) juga meneliti pengaruh manajemen modal kerja dan likuditas terhadap profitabilitas pada industri farmasi yang terdaftar di Bursa Efek Indonesia (BEI). Hasil penelitian tersebut menunjukkan bahwa manajemen modal kerja tidak memiliki pengaruh positif secara parsial terhadap profitabilitas, sedangkan likuiditas berpengaruh terhadap profitabilitas. Dan secara simultan, manajemen modal kerja dan likuiditas secara bersama-sama berpengaruh signifikan terhadap profitabilitas.

Data di Bursa Efek Indonesia (2018), pada periode tahun 2014 sampai dengan 2016 
terdapat ada beberapa perusahaan mengalami penurunan dalam rasio profitabilitas.

Tabel 1. Perkembangan Profitabilitas Perusahaan Pertambangan di BEI 2016 - 2019

\begin{tabular}{lllllll}
\hline No. & Kode & \multicolumn{2}{c}{ Nama Perusahaan } & \multicolumn{4}{c}{ Tahun } \\
\cline { 4 - 7 } 1. & ADRO & Adaro Energy Tbk. & $\mathbf{2 0 1 6}$ & $\mathbf{2 0 1 7}$ & $\mathbf{2 0 1 8}$ & $\mathbf{2 0 1 9}$ \\
2. & CTH & CITATAH Tbk. & 0.034 & 0.029 & 0.025 & 0.110 \\
3. & ELSA & Elnusa Tbk. & 0.001 & 0.002 & 0.030 & 0.403 \\
4. & INCO & Vakle Indonesia Tbk. & 0.056 & 0.101 & 0.086 & 0.050 \\
5. & ITMG & Indo Tambangraya Megah Tbk. & 0.017 & 0.074 & 0.020 & 0.010 \\
6. & KKGI & Resource Alam Indonesia Tbk. & 0.159 & 0.125 & 0.121 & 0.140 \\
7. & PTBA & Tambang Batubara Bukit Asam & 0.111 & 0.116 & 0.086 & 0.150 \\
& & (Persero) Tbk. & & & & \\
8. & TOBA & Toba Bara Sejahtra Tbk. & 0.163 & 0.075 & 0.059 & 0.170 \\
9. & TINS & Timah (Persero) Tbk. & 0.166 & 0.153 & 0.059 & -0.03 \\
\hline
\end{tabular}

Sumber: Bursa Efek Indonesia (BEI), 2020

Tabel 1 memperlihatkan perkembangan profitabilitas perusahaan pertambangan di BEI. Tabel ini direfleksikan pada Gambar 1 berikut ini.

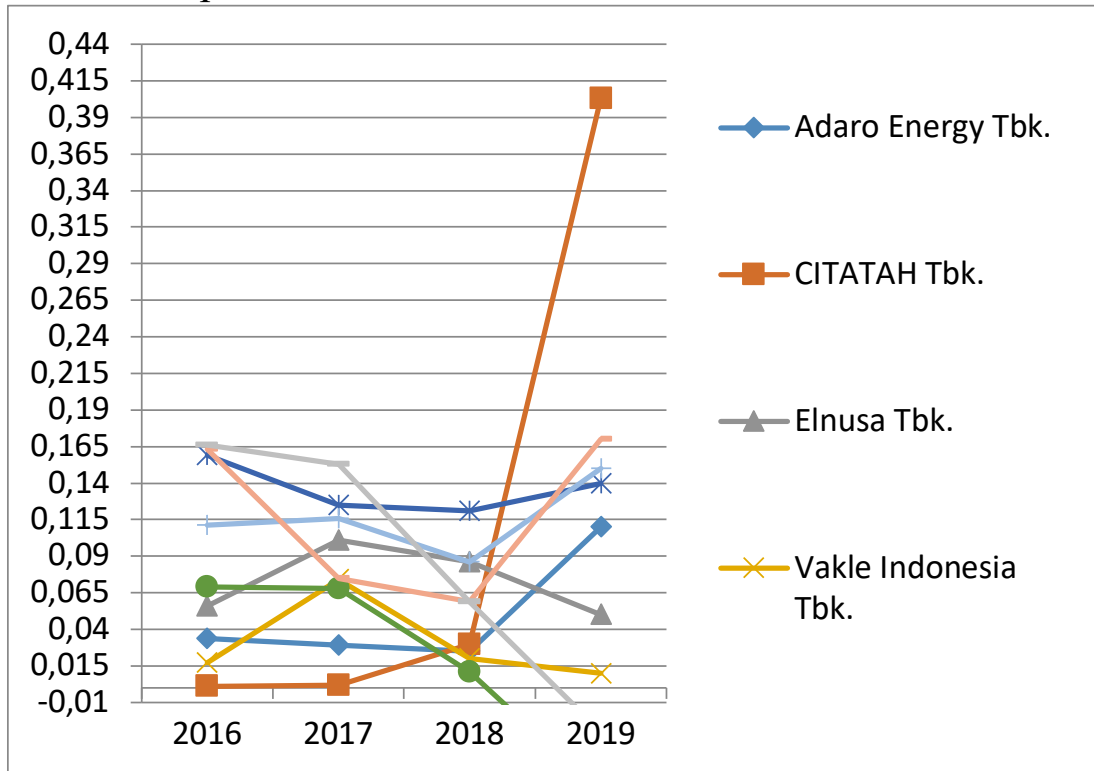

Gambar 1. Fluktuasi Perkembangan Profitabilitas

Sumber: Hasil olah tabel, 2020

Tabel dan gambar di atas memperlihatkan fluktuasi Perkembangan Profitabilitas Perusahaan Pertambangan di BEI 2016 - 2019. Perkembangan naik turunya profitabilitas perusahaan jika dihubungkan dengan perputaran modal, skala perusahaan, likuiditas dan leverage belum proporsional. Fenomena ini mejadi daya tarik peneliti untuk meneliti dengan judul "Kinerja Keuangan Terhadap Profitabilitas Pada Perusahaan Pertambangan di Bursa Efek Indonesia".

\section{Tinjauan Literatur}

\subsection{Profitabilitas}

a. Pengertian Profitabilitas 
Sartono (2014:122) mengemukakan bahwa profitabilitas adalah "Kemampuan perusahaan memperoleh laba dalam hubungannya dengan penjualan, total aset maupun modal sendiri”.

\section{b. Rasio Profitabilitas}

Kasmir (2015:196) mengemukakan bahwa "Rasio Profitabilitas merupakan rasio untuk menilai kemampuan perusahaan dalam mencari keuntungan". Rasio profitabilitas digunakan untuk mengukur kinerja perusahaan dalam upaya memperoleh laba. Rasio ini juga memberikan ukuran tingkat efektivitas manajemen suatu perusahaan yang ditunjukkan dari laba yang dihasilkan dari penjualan dan investasi.

Terdapat beberapa cara untuk mengukur tingkat profitabilitas suatu perusahaan yaitu :

1).Gross Profit Margin, ukuran persentase dari setiap hasil penjualan sesudah perusahaan membayar harga pokok penjualan. Semakin tinggi gross profit margin maka semakin baik. Rumus untuk mencari GPM adalah sebagai berikut:

Gross profit margin $=\frac{\text { gross profit }}{\text { sales }} \times 100 \%$

2). Net Profit Margin, ukuran untuk mengukur persentase keuntungan perusahaan setelah dikurangi semua biaya dari pengeluaran termasuk bunga dan pajak.

Net profit margin $=\frac{\text { net income }}{\text { sales }} \times 100 \%$

3). Return On Asset (ROA), ukuran keefektifan manajemen dalam menghasilkan laba dengan aktiva yang tersedia.

ROA $=\frac{\text { Laba bersih setelah pajak }}{\text { Total asset }} x 100 \%$

4). Return On Investment (ROI), kemampuan perusahaan menghasilkan laba dari aktiva yang dipergunakan. Dengan mengetahui rasio ini akan dapat diketahui apakah perusahaan efisien dalam memanfaatkan aktivanya dalam kegiatan perusahaannya.

ROI $=\frac{\text { Laba Bersih Setelah Pajak }}{\text { Total Invesment }} \boldsymbol{x} \mathbf{1 0 0} \%$

5). Return On Equity (ROE), ukuran pengembalian yang diperoleh pemilik atas investasi di perusahaan.

$\mathrm{ROE}=\frac{\text { Laba rugi Setelah Pajak }}{\text { Total equity }} \boldsymbol{x} \mathbf{1 0 0} \%$

\subsection{Working Capital Turnover}

a. Pengertian Modal Kerja

Sawir (2016:72) mengemukakan bahwa " Modal kerja adalah keseluruhan aset lancar yang dimiliki perusahaan atau dengan pula dimaksudkan sebagai dana yang tersedia 
untuk membiayai kegiatan operasi perusahaan sehari-hari”. Munawir (2015:114) mengemukakan bahwa dinyatakan ada tiga konsep definisi modal kerja yaitu : konsep kuantitatif, konsep kualitatif, dan konsep fungsional. Dalam konsep kuantitatif, pengertian modal kerja adalah meliputi seluruh aktiva lancar yang memiliki tingkat perputaran yan pendek yakni berupa kas, piutang, persediaan maupun persekot biaya. Pada konsep kualitatif, modal kerja adalah aktiva lancar yang benar-benar digunakan untuk kegiatan operasional yang telah dikurangi dengan hutang lancar. Sedangkan, konsep fungsional, modal kerja adalah modal yang benar-benar digunakan untuk menghasilkan pendapatan periode berjalan (current income) atau periode saat ini saja bukan untuk periode selanjutnya.

\section{b. Perputaran Modal Kerja (Working Capital Turnover)}

Manajemen penggunaan modal kerja dapat diuji dengan menggunakan rasio perputaran modal kerja (working capital turnover), yakni perbandingan antara penjualan dengan jumlah keseluruhan aset lancar yang dimiliki suatu perusahaan pada suatu periode tertentu. Periode perputaran modal kerja dimulai saat dimana kas diinvestasikan dalam komponen-komponen modal kerja sampai saat dimana kembali lagi menjadi kas. Makin pendek periode tersebut, makin cepat perputarannya atau makin tinggi tingkat perputarannya. Berapa lama periode perputaran modal kerja adalah tergantung pada berapa lama periode perputaran masing-masing komponen modal tersebut.

Formulasi untuk menghitung working capital turnover

(WCT) adalah sebagai berikut:

Working capital turn over $=\frac{\text { Sales }}{\text { (Current Assets - Current Liabilities) }} \boldsymbol{x 1 0 0 \%}$

\subsection{Firm Size}

\section{a. Pengertian Firm Size}

Firm Size atau ukuran perusahaan secara umum dapat diartikan sebagai suatu skala yang dapat dihitung berdasarkan jumlah aset yang dimiliki perusahaan atau besarnya tingkat penjualan bersih suatu perusahaan. Perusahaan besar lebih memiliki akses yang lebih mudah ke pasar modal dibandingkan dengan perusahaan kecil. Kusuma (2014:118) mengemukakan bahwa ada tiga teori yang secara implisit menjelaskan hubungan antara ukuran perusahaan dan tingkat keuntungan, antara lain :

1). Teori teknologi, yang menekankan pada modal fisik, economies of scale dan lingkup sebagai faktor-faktor yang menentukan besarnya ukuran perusahaan yang optimal serta pengaruhnya terhadap profitabilitas.

2). Teori organisasi, menjelaskan hubungan profitabilitas dengan ukuran perusahaan yang dikaitkan dengan biaya transaksi organisasi dan rentang biaya-biaya pengendalian.

3). Teori institusional mengaitkan ukuran perusahaan dengan faktorfaktor seperti sistem perundang-undangan, peraturan anti-trust, perlindungan patent, ukuran pasar dan perkembangan pasar keuangan.

Teori teknologi mengindikasikan bahwa perkembangan teknologi akan meningkatkan kapasitas produksi (jumlah output yang dihasilkan) sehingga memungkinkan perusahaan menghasilkan laba yang lebih besar. Teori organisasi mengindikasikan bahwa semakin 
besar skala perusahaan maka profitabilitas juga akan meningkat, akan tetapi pada titik tertentu ukuran perusahaan akhirnya akan menurunkan laba (profit) perusahaan. Hal ini mengindikasikan perusahaan untuk memiliki total aset dalam jumlah yang optimal.

\subsection{Likuiditas}

\section{a. Pengertian Likuiditas}

Kasmir (2015:110) mengemukakan bahwa "rasio likuiditas merupakan rasio yang menggambarkan kemampuan perusahaan dalam memenuhi kewajiban jangka pendek". Fungsi lain rasio likuiditas adalah untuk menunjukkan atau mengukur kemampuan perusahaan dalam memenuhi kewajibannya yang jatuh tempo, baik kewajiban kepada pihak luar perusahaan (likuiditas badan usaha) maupun di dalam perusahaan (likuiditas perusahaan).

Terdapat beberapa cara untuk mengukur tingkat likuiditas suatu perusahaan yaitu:

1). Rasio Lancar (Current Ratio)

Garrison dkk (2007:600) mengemukakan bahwa "rasio lancar (Current Ratio) adalah aktiva lancar perusahaan yang dibagi dengan kewajiban lancar"

Rumus dari current ratio adalah sebagai berikut:

$$
\text { Current Ratio }=\text { Current Asset } / \text { Current Liabilities x 100\% }
$$

\section{2). Rasio Cepat (Quick Ratio)}

Kasmir (2015:137) mengemukakan bahwa "rasio Cepat (Quick Ratio) merupakan rasio yang menunjukkan kemampuan perusahaan dalam memenuhi atau membayar kewajiban atau utang lancar (utang jangka pendek) dengan Aset lancar tanpa memperhitungkan nilai sediaan (inventory)".

Quick ratio dapat dihitung dengan formula :

$$
\text { Quick Ratio }=\frac{\text { Current Asset }- \text { Inventory }}{\text { Current Liabilities }} \boldsymbol{x 1 0 0 \%}
$$

\subsection{Leverage}

\section{a. Pengertian Leverage}

Seperti yang diketahui, dalam mendanai usahanya, perusahaan memiliki beberapa sumber dana. Sumber-sumber dana yang dapat diperoleh adalah pinjaman atau modal sendiri. Keputusan untuk memilih menggunakan modal sendiri atau modal pinjaman haruslah digunakan beberapa perhitungan yang matang. Dalam hal ini leverage ratio (rasio solvabilitas) merupakan rasio yang digunakan untuk mengukur sejauh mana aktivitas perusahaan dibiayai dengan utang. Artinya, besarnya jumlah utang yang digunakan perusahaan untuk membiayai kegiatan usahanya jika dibandingkan dengan menggunakan modal sendiri.

Debt to equity ratio (DER) sebagai parameter dari rasio leverage. Karena bagi perusahaan, semakin tinggi rasio ini akan semakin tinggi resiko keuangan perusahaan dan mempengaruhi profitabilitas perusahaan tersebut. Rasio ini digunakan untuk menilai utang dengan ekuitas. Rasio ini berguna untuk mengetahui dana yang disediakan peminjam (kreditor) dengan pemilik perusahaan.

Rumus dari debt to equity ratio adalah sebagai berikut: 
Debt to Equity Ratio $=\frac{\text { Total Debt }}{\text { Total equity }} \boldsymbol{x} \mathbf{1 0 0} \%$

\subsection{Kerangka Pemikiran}

Peneliti akan menganalisis dengan kerangka pemikiran menghubungkan variabel bebas Working Capital Turnover $\left(X_{1}\right)$, Firm Size $\left(X_{2}\right)$, Likuiditas $\left(X_{3}\right)$, Leverage $\left(X_{4}\right)$ terhadap terhadap variabel terikat profitabilitas $(Y)$ dapat dilihat dalam gambar kerangka pemikiran berikut ini :

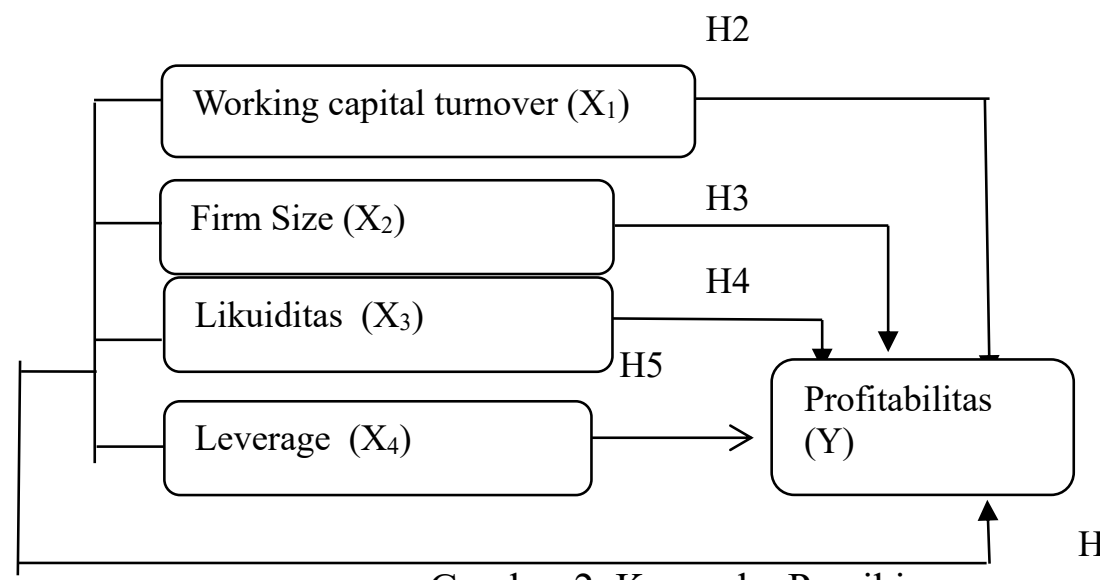

Gambar 2. Kerangka Pemikiran

Sumber: Pemikiran Peneliti berdasarkan teori, 2020

\section{Metodologi Penelitian}

Metode penelitian yang digunakan dalam penelitian ini adalah penelitian asosiatif. Menurut Sugiyono (2009:58) penelitian asosiatif adalah peneltian yang bertujuan untuk mengetahui hubungan antara dua variabel atau lebih. Penelitian ini adalah hubungan kasual, yaitu hubungan yang bersifat sebab akibat.

Tabel 2. Operasionalisasi Variabel.

\begin{tabular}{|c|c|c|c|}
\hline Variabel & Definisi variabel & Indikator & Skala \\
\hline $\begin{array}{l}\text { Profitabilitas } \\
\left(\mathrm{Y}_{1}\right)\end{array}$ & $\begin{array}{l}\text { menilai kemampuan perusahaan } \\
\text { pertambangan di BEI dalam } \\
\text { mencari keuntungan atau laba } \\
\text { dalam suatu periode tertentu }\end{array}$ & $\begin{array}{l}\text { ROA } \\
=\text { EAT/Total asets } \mathrm{x} \\
100 \%\end{array}$ & Ratio \\
\hline $\begin{array}{l}\text { Working Capital } \\
\text { Turnover }\left(\mathbf{X}_{1}\right) \text {. }\end{array}$ & $\begin{array}{l}\text { menunjukkan banyaknya } \\
\text { penjualan yang dapat diperoleh } \\
\text { perusahaan pertambangan di BEI } \\
\text { untuk tiap rupiah modal kerja. }\end{array}$ & $\begin{array}{l}\text { Working capital } \\
\text { turnover }=\text { Sales } / \\
\text { current asets-curent } \\
\text { liabilities x } 100 \%\end{array}$ & Ratio \\
\hline Firm Size $\left(\mathrm{X}_{2}\right)$ & $\begin{array}{l}\text { skala yang dapat dihitung } \\
\text { berdasarkan jumlah aset yang } \\
\text { dimiliki perusahaan atau besarnya } \\
\text { tingkat penjualan bersih suatu } \\
\text { perusahaan pertambangan di BEI. }\end{array}$ & $\begin{array}{l}\text { Size }=\text { Log Natural } \\
\text { Total Assets }\end{array}$ & Ratio \\
\hline
\end{tabular}




$\begin{array}{llrr} & \text { Jurnal Bisnis, Manajemen dan Ekonomi } \\ \text { e-ISSN: 2745-7281 } & & \\ \text { Vol. 2, No. 1, Januari 2021 }\end{array}$

Sumber: Pemikiran Penulis berdasarkan teori, 2020

\subsection{Populasi dan Sampel}

Sampel dalam penelitian ini adalah bagian dari jumlah dan karakteristik yang dimiliki populasi (Sugiyono, 2013:86). Jumlah populasi yang digunakan dalam penelitian ini adalah sebanyak 41 perusahaan dan sampel yang memenuhi kriteria penelitian adalah sebanyak 9 perusahaan.

Adapun yang menjadi kriteria dalam pengambilan sampel adalah sebagai berikut :

1. Perusahan pertambangan yang terdaftar di Bursa Efek Indonesia (BEI) selama periode penelitian yaitu 2015 - 2019

2. Perusahaan yang menyajikan laporan keuangan (neraca, laporan laba Rugi, modal) yang telah diaudit tahun 2015-2019

3. Perusahan pertambangan yang tersebut menerbitkan Capital Market

Directory periode $2015-2019$.

4. Perusahaan yang menyajikan laporan keuangan yang telah diaudit ke publik melalui media massa maupun elektronik tahun $2015-2019$ secara berturut-turut.

Tabel 3. Sampel Perusahaan

\begin{tabular}{|c|c|c|c|c|c|c|c|}
\hline \multirow[t]{2}{*}{ No } & \multirow[t]{2}{*}{ Kode } & \multirow{2}{*}{\multicolumn{2}{|c|}{ Nama Perusahaan }} & \multicolumn{2}{|c|}{$\begin{array}{l}\text { Kriteria } \\
\text { sampel }\end{array}$} & \multicolumn{2}{|c|}{ perusahaan } \\
\hline & & & & 1 & 2 & 3 & 4 \\
\hline 1 & ADRO & Adaro Energy Tbk & & $\sqrt{ }$ & $\sqrt{ }$ & $\sqrt{ }$ & $\sqrt{ }$ \\
\hline 2 & CTTH & CITATAH Tbk & & $\sqrt{ }$ & $\sqrt{ }$ & $\sqrt{ }$ & $\sqrt{ }$ \\
\hline 3 & ELSA & Elnusa Tbk & & $\sqrt{ }$ & $\sqrt{ }$ & $\sqrt{ }$ & $\sqrt{ }$ \\
\hline 4 & INCO & Vakle Indonesia Tbk & & $\sqrt{ }$ & $\sqrt{ }$ & $\sqrt{ }$ & $\sqrt{ }$ \\
\hline 5 & ITMG & Indo Tambangraya Megah Tbk & & $\sqrt{ }$ & $\sqrt{ }$ & $\sqrt{ }$ & $\sqrt{ }$ \\
\hline 6 & KKGI & Resource Alam Indonesia Tbk & & $\sqrt{ }$ & $\sqrt{ }$ & $\sqrt{ }$ & $\sqrt{ }$ \\
\hline 7 & PTBA & $\begin{array}{l}\text { Tambang Batubara Bukit } \\
\text { (Persero) Tbk }\end{array}$ & Asam & $\sqrt{ }$ & $\sqrt{ }$ & $\sqrt{ }$ & $\sqrt{ }$ \\
\hline 8 & TOBA & Toba Bara Sejahtra Tbk & & $\sqrt{ }$ & $\sqrt{ }$ & $\sqrt{ }$ & $\sqrt{ }$ \\
\hline 9 & TINS & Timah (Persero) Tbk & & $\sqrt{ }$ & $\sqrt{ }$ & $\sqrt{ }$ & $\sqrt{ }$ \\
\hline
\end{tabular}

Sumber: http://www.idx.co.id, 2020

Published by: 
Setelah melalui penilaian karakteristik masing-masing perusahaan tambang di bursa Efek Indonesia (BEI), sampel yang memenuhi kriteria penelitian adalah sebanyak 9 perusahaan.

\subsection{Model Analisis}

\subsubsection{Analisis Regresi Linier Berganda}

Berdasarkan permasalahan dan hipotesis yang diajukan, alat teknik analisis statistika yang digunakan adalah analisis regresi linear berganda, model analisis yang digunakan dalam penelitian adalah :

$$
\begin{aligned}
& \mathrm{Y}=\mathrm{a}+\mathrm{b}_{1} \cdot \mathrm{X}_{1}+\mathrm{b}_{2} \cdot \mathrm{X}_{2}+\mathrm{b}_{3} \cdot \mathrm{X}_{3}+\mathrm{b}_{3} \cdot \mathrm{X}_{3}+\mathrm{b}_{4} \cdot \mathrm{X}_{4}+\mathrm{e} \\
& \text { Keterangan : } \\
& \mathrm{Y}=\text { Profitabilitas } \mathrm{a}=\text { Nilai konstanta } \mathrm{b}_{1}-\mathrm{b}_{4}=\text { Nilai koefisien regresi } \\
& \mathrm{X}_{1}=\text { Working Capital Turnover } \quad \mathrm{X}_{2}=\text { Firm Size } \mathrm{X}_{3}=\text { Likuiditas } \\
& \mathrm{X}_{4}=\text { Leverage } \quad \mathrm{e}=\text { Error of term }
\end{aligned}
$$

\subsection{Uji Korelasi dan Koefisien Determinasi}

\subsubsection{Uji Korelasi (R)}

Analisis korelasi adalah salah satu teknik statistik yang digunakan untuk mencari hubungan antara dua variabel atau lebih yang sifatnya kuantitatif. Fungsi utama dari analisis korelasi adalah untuk menentukan seberapa erat hubungan antara satu variabel dengan variabel lainnya. Analisis Korelasi bertujuan untuk mengukur kekuatan hubungan antar variabel, analisis korelasi tidak membedakan antara variabel dependen dengan independen.

\subsubsection{Uji Koefisien Determinasi $\left(\mathrm{R}^{2}\right)$}

Determinasi digunakan dalam kaitannya dengan penggunaan analisis kolerasi untuk melihat besar kecilnya besaran kontribusi atas variabel bebas menjelaskan variabel terikat. Koefisien determinasi disebut juga koefisien penentu, karena varian yang terjadi pada variabel dependen dapat dijelaskan melalui variabel independen. Nilai koefisien determain dilihat dari nilai $\mathrm{R}$ square $\left(\mathrm{R}^{2}\right)$. Jika $\mathrm{R}^{2}=0$, maka tidak ada sedikitpun pengaruh yang diberikan variabel bebas terhadap variabel terkait.

\subsection{Uji Koefisien}

\subsubsection{Uji F (Uji secara Bersama-sama)}

Uji F digunakan untuk menguji pengaruh variabel Working Capital Turnover, Firm Size, Likuiditas dan Leverage secara bersama-sama terhadap Profitabilitas perusahaan pertambangan di Bursa Efek Indonesia.

Langkah-langkah pengujiannya adalah sebagai berikut :

1) Menentukan formula hipotesis

Ho: tidak ada pengaruh Working Capital Turnover, Firm Size, Likuiditas dan Leverage secara bersama-sama terhadap Profitabilitas perusahaan pertambangan di Bursa Efek Indonesia.

Ha: ada pengaruh Working Capital Turnover, Firm Size, Likuiditas, dan Leverage secara bersama-sama terhadap Profitabilitas perusahaan pertambangan di Bursa Efek Indonesia.

2). Menentukan tingkat signifikan, digunakan adalah $0,05(\alpha=5 \%)$ 
3). Menentukan Kriteria Pengujian

a). Jika $\mathrm{F}$ hit $>\mathrm{F}$ tabel atau sig $\mathrm{F}<\alpha(0,05)$, maka Ho ditolak dan Ha diterima, artinya ada pengaruh Working Capital Turnover, Firm Size, Likuiditas dan Leverage secara bersama-sama terhadap Profitabilitas perusahaan pertambangan di Bursa Efek Indonesia.

b). Jika $\mathrm{F}$ hit $\leq \mathrm{F}$ tabel atau sig $\mathrm{F} \geq \alpha(0,05)$, maka Ho diterima dan $\mathrm{Ha}$ ditolak, artinya tidak ada pengaruh Working Capital Turnover, Firm Size, Likuiditas dan Leverage secara bersama-sama terhadap Profitabilitas perusahaan pertambangan di Bursa Efek Indonesia.

\subsubsection{Uji t (Uji Secara Parsial)}

Uji t digunakan untuk menguji pengaruh masing-masing variabel terhadap profitabilitas. Pengaruh Working Capital Turnover terhadap Profitabilitas perusahaan pertambangan di Bursa Efek Indonesia. Pengaruh Firm Size terhadap Profitabilitas perusahaan pertambangan di Bursa Efek Indonesia. Pengaruh Likuiditas terhadap Profitabilitas perusahaan pertambangan di Bursa Efek Indonesia. Pengaruh Leverage terhadap Profitabilitas perusahaan pertambangan di Bursa Efek Indonesia.

Langkah-langkah pengujiannya adalah sebagai berikut :

1) Menentukan formula hipotesis

Ho: tidak ada pengaruh ada pengaruh Working Capital Turnover, Firm Size, Likuiditas dan Leverage secara parsial terhadap terhadap Profitabilitas perusahaan pertambangan di Bursa Efek Indonesia.

Ha: ada pengaruh ada pengaruh Working Capital Turnover, Firm Size, Likuiditas dan Leverage secara parsial terhadap terhadap Profitabilitas perusahaan pertambangan di Bursa Efek Indonesia.

2) Menentukan tingkat signifikan, digunakan adalah 0,05 ( $\alpha=5 \%)$

3) Menentukan Kriteria Pengujian

a). Jika $\mathrm{t}$ hit $>\mathrm{t}$ tabel atau sig $\mathrm{t}<\alpha(0,05)$, maka Ho ditolak dan Ha diterima, artinya ada pengaruh Working Capital Turnover, Firm Size, Likuiditas dan Leverage secara parsial terhadap terhadap Profitabilitas perusahaan pertambangan di Bursa Efek Indonesia.

b). Jika $\mathrm{t}$ hit $\leq \mathrm{t}$ tabel atau sig $\mathrm{t} \geq \alpha(0,05)$, maka Ho diterima dan Ha ditolak, artinya tidak ada ada pengaruh Working Capital Turnover, Firm Size, Likuiditas dan Leverage secara parsial terhadap terhadap Profitabilitas perusahaan pertambangan di Bursa Efek Indonesia.

\section{Hasil dan Pembahasan}

\subsection{Hasil Penelitian}

Penelitian ini menggunakan data panel, adapun alat analisis yang akan digunakan untuk melihat pengaruh Working Capital Turnover $\left(X_{1}\right)$, Firm Size $\left(X_{2}\right)$, Likuiditas $\left(X_{3}\right)$, Leverage $\left(X_{4}\right)$ terhadap profitabilitas $(\mathrm{Y})$ pada perusahaan pertambangan di Bursa Efek Indonesia (BEI) periode 2015-2019 adalah metode regresi data panel.

\subsection{Hasil Pengujian Asumsi Klasik.}

Uji asumsi klasik data berbentuk panel menggunakan uji autokorelasi, uji heterokedastisitas dan multikolinearitas.. 
a. Uji Autokorelasi

Uji Autokorelasi (uji Durbin Watson) merupakan salah satu uji yang dipakai untuk memriksa ada atau tidaknya autokorelasi antar variabel bebas. Hampir semua program statistis menyediakan fasilitas untuk menghitung nilai $d$. Nilai $d$ berkisar antara 0 sampai dengan 4, dengan penentuan jika nilai $d$ :

1) Berada diantara 0 - 1,3357; maka berarti bahwa Ho tolak (ada autokorelasi positif).

2) Berada diantara 1,3357 - 1,7200; maka bearti bahwa tidak dapat diputuskan.

3) Berada diantara 1,7200 - 2,6643; maka berarti bahwa Ho terima (tidak ada autokorelasi).

4) Berada diantara 2,6643 - 2,800; maka berarti bahwa tidak dapat diputuskan.

5) Berada diantara 2,800 - 4,00; maka berarti bahwa Ho tolak (ada autokorelasi negatif).

Uji autokorelasi dalam penelitian ini menggunakan uji Durbin Watson, berikut tabel hasil uji statistik:

Tabel 4. Uji Autokorelasi dengan Durbin-Watson

\begin{tabular}{llll}
\hline \hline R-squared & 0.851393 & Mean dependent var & 0.068533 \\
Adjusted R-squared & 0.766474 & S.D. dependent var & 0.055276 \\
S.E. of regression & 0.026712 & Akaike info criterion & -4.126306 \\
Sum squared resid & 0.019979 & Schwarz criterion & -3.443789 \\
Log likelihood & 109.8419 & Hannan-Quinn criter. & -3.871871 \\
F-statistic & 10.02600 & Durbin-Watson stat & 2.163102 \\
Prob(F-statistic) & 0.000000 & & \\
\hline \hline
\end{tabular}

Sumber: Eviews Versi 7.0. for Windows (Lampiran)

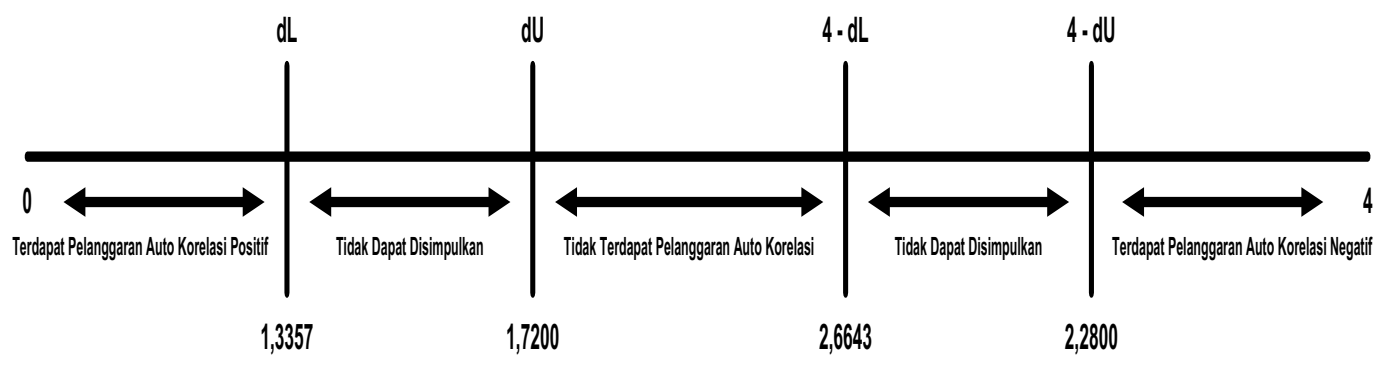

Gambar 3. Estimasi Uji Autokorelasi

Berdasarkan Tabel di atas diketahui nilai Durbin Watson sebesar 2.163102; berarti masih dalam range 1,7200 - 2,6643, sehingga dengan demikian dapat disimpulkan bahwa datadata yang digunakan dalam penelitian ini tidak mengandung autokorelasi, dan layak untuk dianalisis dengan regresi linier berganda.

b. Uji Heterokedastisitas

Uji heterokedastisitas dalam penelitian ini menggunakan uji glejser, berikut tabel hasil uji statistik:

Tabel 5. Uji Heterokedastisitas dengan Metode Glejser

\begin{tabular}{lllll}
\hline \hline Variable & Coefficient & Std. Error & t-Statistic & Prob. \\
\hline \hline
\end{tabular}




$\begin{array}{lllll}\mathrm{C} & 0.008252 & 0.035310 & 0.233695 & 0.8164 \\ \mathrm{X} 1 & -0.000774 & 0.001132 & -0.683502 & 0.4982 \\ \mathrm{X} 2 & 0.000183 & 0.001910 & 0.096071 & 0.9239 \\ \mathrm{X} 3 & 0.008803 & 0.004832 & 1.821598 & 0.0760 \\ \mathrm{X} 4 & 0.029112 & 0.010642 & 2.735741 & 0.0092\end{array}$

Sumber: data diolah, Eviews Versi 7.0. for Windows 2020

Berdasarkan Tabel di atas, hasil tampilan output variabel X1, X2, X3 menunjukkan nilai Probabilitas variabel diatas 0,05 , menyatakan bahwa hipotesis alternatif adanya heterokedastisitas dalam model ditolak, sedangkan untuk variabel X4 menunjukkan nilai Probabilitas variabel dibawah 0,05 , menyatakan bahwa hipotesis alternatif adanya heterokedastisitas dalam model diterima.

c. Uji Multikolinieritas

Model regresi yang baik eharusnya tidak terjadi korelasi diantara variabel bebas (tidak terjadi multikolinieritas).

Tabel 6. Uji Multikolinieritas Dengan Korelasi

\begin{tabular}{lllll}
\hline & \multicolumn{1}{r}{ X1 } & \multicolumn{1}{r}{ X2 } & \multicolumn{1}{r}{ X3 } & \multicolumn{1}{c}{ X4 } \\
X1 & 1 & -0.15962 & -0.23151 & 0.22100 \\
X2 & -0.15962 & 1 & 0.00490 & -0.04221 \\
X3 & -0.23151 & 0.00490 & 1 & -0.29977 \\
X4 & 0.22100 & -0.04221 & -0.29977 & 1 \\
\hline
\end{tabular}

Sumber: data diolah, Eviews Versi 7.0. for Windows 2020

Berdasarkan Tabel di atas diketahui bahwa nilai korelasi absolut semua variabel independen lebih besar dari 0,800 . Nilai semua variabel independen nilai korelasi absolutnya lebih kecil dari 0,800 . Berdasarkan kriteria dalam pengambilan keputusan dapat disimpulkan bahwa tidak terjadi multikolinieritas.

\subsection{Uji Normalitas}

Salah satu uji asumsi klasik adalah uji normalitas data. Uji normalitas data digunakan untuk mnentukan bahwa data yang akan diuji merupakan data yang memiliki distribusi normal. Permasalahan data yang tidak berdistribusi normal tidak akan menjadi masalah apabila jumlah sampel sudah lebih dari 30 observasi, karena jumlah sampel yang lebih dari 30 akan mendekati distribusi normal (Gujarati, 2003). Dalam penelitian ini memiliki jumlah sampel 45 dimana jumlah tersebut lebih dari 30 yang dapat dikatakan bahwa data berdistribusi normal. Namun untuk memberikan kepastian bahwa data tersebut berdistribusi normal, maka dilakukan pengujian normalitas data.

Pengujian normalitas data dalam penelitian ini menggunakan uji Jarque-Bera pada program eviews version 9.0. Berikut adalah gambar hasil uji normalitas data. 


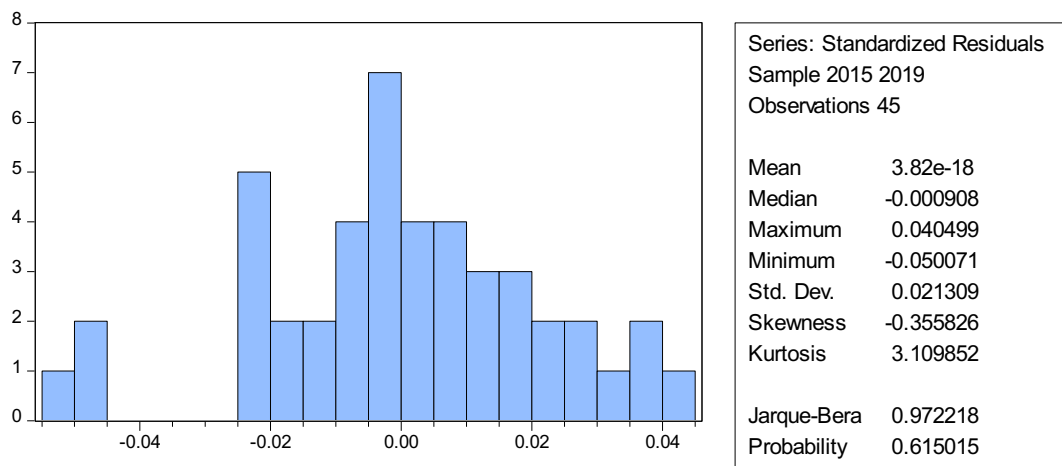

Gambar 4. Uji Normalitas

Sumber: data diolah, Eviews Versi 7.0. for Windows 2020.

Berdasarkan hasil output di atas menunjukkan bahwa nilai Jarque- Bera 0,972218 dengan probabilitas 0.615015 . Dengan nilai probabilitas 0.615015 yang lebih besar dari taraf signifikan 0,005 maka dapat disimpulkan bahwa data dalam penelitian ini telah berdistribusi normal.

\subsection{Model dan Rancangan Uji Hipotesis}

Untuk menjawab rumusan masalah tentang "Bagaimana Pengaruh Working Capital Turnover, Firm Size, Likuiditas dan Leverage secara parsial dan bersama-sama terhadap Profitabilitas pada Perusahaan Pertambangan di Bursa Efek Indonesia (BEI).", maka dilakukan analisis regresi linear berganda, analisis koefisien determinasi dan uji koefisien regresi.

a. Uji Analisis Regresi Berganda

Berdasarkan hasil perhitungan dengan menggunakan Eviews Versi 7.0. for Windows diperoleh hasil uji regresi linier berganda, yaitu sebagai berikut :

Tabel 7. Hasil Pengujian Regresi Linear Berganda dan Uji Hipotesis t

Dependent Variable: Y

Method: Panel Least Squares

Date: 01/12/21 Time: 12:56

Sample: 20152019

Periods included: 5

Cross-sections included: 9

Total panel (balanced) observations: 45

\begin{tabular}{lllll}
\hline \hline Variable & Coefficient & Std. Error & t-Statistic & Prob. \\
\hline \hline C & -0.006571 & 0.049058 & -0.133941 & 0.8944 \\
X1 & 0.000812 & 0.001341 & 0.605407 & 0.5498 \\
X2 & -0.000143 & 0.002111 & -0.067701 & 0.9465 \\
X3 & 0.036545 & 0.012924 & 2.827580 & 0.0086 \\
X4 & -0.011253 & 0.016780 & -0.670593 & 0.5080 \\
\hline \hline
\end{tabular}

Sumber: data diolah, Eviews Versi 7.0. for Windows 2020 
Persamaan linear berganda dalam penelitian ini adalah :

$$
\text { Yit }=\mathbf{a}+\mathbf{b}_{1} \mathbf{X}_{1} i t+\mathbf{b}_{2} \mathbf{X}_{2} i t+\mathbf{b}_{3} \mathbf{X}_{3} i t+\mathbf{b}_{4} \mathbf{X}_{4} i t+\text { eit }
$$

Yit $=-\mathbf{- 0 , 0 0 6 5 7 1}+0,000812 X_{1}-0,000143 X_{2}+0,036545 X_{3}-0,011253 X_{4}+e$

Keterangan :

$$
\begin{array}{ll}
\text { Yit } & =\text { Profitabilitas } \\
\mathrm{X}_{1}=\text { Working Capital Turnover } & \\
\mathrm{X}_{2} \quad=\text { Firm Size } \mathrm{X}_{3} \quad=\text { Likuiditas } \mathrm{X}_{4} \quad=\text { Leverage } \\
\mathrm{a} \quad=\text { Nilai konstanta, perpotongan garis pada sumbu X } \\
\mathrm{b}_{1} \cdot \mathrm{b}_{2} \cdot \mathrm{b}_{3} . \mathrm{b}_{4}=\text { Koefisien regresi variabel X } \\
\text { eit } \quad=\text { error term. }
\end{array}
$$

Dari hasil estimasi regresi data panel, maka dapat dijabarkan dalam penjelasan berikut ini.

a. Signifikansi Pengaruh Working Capital Turnover $\left(\mathrm{X}_{1}\right)$ terhadap Profitabilitas (Y)

Koefisien regresi variabel Working Capital Turnover $\left(\mathrm{X}_{1}\right)$ sebesar 0,000812, variabel Working Capital Turnover berslope positif artinya, ketika terjadi kenaikan Working Capital Turnover perusahaan menyebabkan Profitabilitas perusahaan meningkat.

b. Signifikansi Pengaruh Firm Size $\left(\mathrm{X}_{2}\right)$ secara parsial terhadap Profitabilitas (Y)

Koefisien regresi variabel Firm Size $\left(\mathrm{X}_{2}\right)$ sebesar -0,000143, variabel Firm Size berslope negatif artinya, ketika terjadi kenaikan Firm Size perusahaan menyebabkan Profitabilitas perusahaan menurun.

c. Signifikansi Pengaruh Likuiditas $\left(\mathrm{X}_{3}\right)$ secara parsial terhadap Profitabilitas (Y)

Koefisien regresi variabel Likuiditas $\left(\mathrm{X}_{3}\right)$ sebesar 0,036545 , variabel likuiditas berslope positif artinya, ketika terjadi kenaikan Likuiditas perusahaan menyebabkan Profitabilitas perusahaan meningkat.

d. Signifikansi Pengaruh Leverage $\left(\mathrm{X}_{4}\right)$ secara parsial terhadap Profitabilitas (Y)

Koefisien regresi variabel Leverage $\left(\mathrm{X}_{4}\right)$ sebesar -0,011253, variabel Leverage berslope negatif artinya, ketika terjadi kenaikan Leverage perusahaan menyebabkan Profitabilitas perusahaan menurun.

\subsection{Hasil Pengujian Koefisien Determinan}

Koefisien determinasi pada intinya mengukur seberapa jauh kemampuan model dalam menerangkan variasi variabel independen. Nilai determinasi adalah antara satu dan nol. Nilai $\mathrm{R}^{2}$ yang kecil berarti kemampuan variabel-variabel independen dalam menjelaskan variabel dependen terbatas. Nilai yang mendekati satu berarti variabel-variabel independen memberikan hampir semua informasi yang dibutuhkan untuk memprediksi variasi variabel dependen. (Ghozali, 2013).

Tabel 8. Koefisien Determinasi $\mathrm{R}^{2}$

Cross-section fixed (dummy variables)

Period fixed (dummy variables) 
R-squared

0.851393

Mean dependent var

0.068533

Adjusted R-squared

0.766474

S.D. dependent var

0.055276

Sumber: data diolah, Eviews Versi 7.0. for Windows 2020.

Tabel 8 bergambarkan Kemampuan model dalam menerangkan variabel Working Capital Turnover $\left(\mathrm{X}_{1}\right)$, Firm Size $\left(\mathrm{X}_{2}\right)$, Likuiditas $\left(\mathrm{X}_{3}\right)$, Leverage $\left(\mathrm{X}_{4}\right)$ terhadap profitabilitas $(\mathrm{Y})$ adalah sebesar 76,64\% (Adjusted-R-squared, data sekunder), sisanya sebesar 23,36\% variabel lain yang tidak diteliti dalam penelitian ini. Artinya variabel independen memberikan hampir semua informasi yang dibutuhkan untuk memprediksi variabel dependen.

\subsection{Hasil Pengujian Hipotesis}

a) Uji t (Parsial)

Dalam pengujian ini pengaruh parsial dari masing-masing variable bebas terhadap variable terikat dapat dijelaskan menggunakan uji t dengan pengujian sebagai berikut

Ho ditolak : Sig $\mathrm{t}<0,05$ dan $\mathrm{t}_{\text {hitung }}>\mathrm{t}$ table

Ho tidak dapat ditolak: Sig $\mathrm{t} \geq 0,05$ atau $\mathrm{t}_{\text {hitung }} \leq \mathrm{t}$ table

$\mathrm{H}_{1}$ : Tidak terdapat pengaruh yang positif antara variabel bebas (Working Capital Turnover, Firm Size, Likuiditas, Leverage) terhadap variabel terikat (Profitabilitas) secara simultan.

$\mathrm{Ha}_{1}$ : Terdapat pengaruh yang positif antara variabel bebas (Working Capital Turnover, Firm Size, Likuiditas, Leverage) terhadap variabel terikat (Profitabilitas) secara simultan. Untuk menentukan tabel digunakan taraf nyata sebesar 5\% dengan derajat kebebasan df(n-2). Jadi Hipotesisnya adalah :

1) Jika Sig $t<0,05$ dan $t_{\text {hitung }}>t_{\text {table }}$ maka Terdapat pengaruh yang positif antara variabel bebas (Working Capital Turnover, Firm Size, Likuiditas, Leverage) terhadap variabel terikat (Profitabilitas) secara simultan atau Ho ditolak dan Ha diterima.

2) Jika Sig $t \geq 0,05$ atau $t_{\text {hiutng }} \leq t$ table maka Tidak terdapat pengaruh yang positif antara variabel bebas (Working Capital Turnover, Firm Size, Likuiditas, Leverage) terhadap variabel terikat (Profitabilitas) secara simultan. atau Ha diterima dan Ho ditolak.

Pengujian $t$ bertujuan untuk melihat pengaruh variabel bebas secara parsial terhadap variabel terikat.

Tabel 9. Nilai Uji t (Parsial)

Dependent Variable: Y

Method: Panel Least Squares

Date: 01/12/21 Time: 12:56

Sample: 20152019

Periods included: 5

Cross-sections included: 9

Total panel (balanced) observations: 45

\begin{tabular}{lllll}
\hline \hline Variable & Coefficient & Std. Error & t-Statistic & Prob. \\
\hline \hline C & -0.006571 & 0.049058 & -0.133941 & 0.8944 \\
X1 & 0.000812 & 0.001341 & 0.605407 & 0.5498 \\
X2 & -0.000143 & 0.002111 & -0.067701 & 0.9465
\end{tabular}

Published by: 


$\begin{array}{lllll}\text { X3 } & 0.036545 & 0.012924 & 2.827580 & 0.0086 \\ \text { X4 } & -0.011253 & 0.016780 & -0.670593 & 0.5080\end{array}$

Sumber: data diolah, Eviews Versi 7.0. for Windows 2020.

Berdasarkan Tabel 9 hasil perhitungan Nilai Uji t (parsial), maka pengaruh variable bebas terhadap variabel terikat, yaitu :

\section{a. Signifikansi Pengaruh Working Capital Turnover $\left(\mathrm{X}_{1}\right)$ terhadap Profitabilitas $(\mathrm{Y})$}

Berdasarkan pada Tabel 9 di atas, dapat dilihat bahwa nilai t-hitung pengaruh Working Capital Turnover $\left(\mathrm{X}_{1}\right)$ terhadap Profitabilitas $(\mathrm{Y})$ sebesar 0,605407 dan nilai signifikansi (Probabilitas) sebesar 0,5498, berarti nilai thitung $(0.605407)<t_{\text {tabel }}(2,01290)$ dan nilai Signifikansi $(0,5498)>\alpha(0,05)$, sehingga Ho diterima dan Ha ditolak, artinya bahwa Working Capital Turnover tidak berpengaruh signifikan terhadap Profitabilitas pada perusahaan pertambangan di Bursa Efek Indonesia (BEI). Koefisien regresi variabel Working Capital Turnover $\left(\mathrm{X}_{1}\right)$ sebesar 0,000812, variabel Working Capital Turnover berslope positif artinya, ketika terjadi kenaikan Working Capital Turnover perusahaan menyebabkan Profitabilitas perusahaan meningkat.

\section{b. Signifikansi Pengaruh Firm Size $\left(\mathrm{X}_{2}\right)$ secara parsial terhadap Profitabilitas (Y)}

Nilai $t_{\text {hitung }}$ pengaruh Firm Size $\left(\mathrm{X}_{2}\right)$ terhadap Profitabilitas $(\mathrm{Y})$, adalah sebesar -0,067701; maka thitung $(-0,067701)>t_{\text {tabel }}(2,01290)$ dan nilai signifikan (Sig. t) sebesar 0,9465, berarti Sig t $(0,9465)>\alpha(0,05)$, sehingga Ho diterima dan Ha ditolak, artinya bahwa Firm Size tidak berpengaruh signifikan terhadap Profitabilitas pada perusahaan pertambangan di Bursa Efek Indonesia (BEI). Koefisien regresi variabel Firm Size $\left(\mathrm{X}_{2}\right)$ sebesar -0,000143, variabel Firm Size berslope negatif artinya, ketika terjadi kenaikan Firm Size perusahaan menyebabkan Profitabilitas perusahaan menurun.

\section{c. Signifikansi Pengaruh Likuiditas $\left(\mathrm{X}_{3}\right)$ secara parsial terhadap Profitabilitas $(\mathrm{Y})$}

Nilai thitung pengaruh Likuiditas $\left(\mathrm{X}_{3}\right)$ terhadap Profitabilitas $(\mathrm{Y})$, adalah sebesar 2,827580; maka $t_{\text {hitung }}(2,827580)>t_{\text {tabel }}(2,01290)$ dan nilai signifikan (Sig. t) sebesar 0,0086, berarti Sig t $(0,0086)<\alpha(0,05)$, sehingga Ha diterima dan Ho ditolak, artinya bahwa Likuiditas berpengaruh yang signifikan terhadap Profitabilitas pada perusahaan pertambangan di Bursa Efek Indonesia (BEI). Koefisien regresi variabel Likuiditas $\left(\mathrm{X}_{3}\right)$ sebesar 0.036545, variabel likuiditas berslope positif artinya, ketika terjadi kenaikan Likuiditas perusahaan menyebabkan Profitabilitas perusahaan meningkat.

\section{d. Signifikansi Pengaruh Leverage $\left(\mathrm{X}_{4}\right)$ secara parsial terhadap Profitabilitas $(\mathrm{Y})$}

Nilai thitung $_{\text {pengaruh Leverage }}\left(\mathrm{X}_{4}\right)$ terhadap Profitabilitas $(\mathrm{Y})$, adalah sebesar -0,670593; maka $t_{\text {hitung }}(-0,670593)>t_{\text {tabel }}(2,01290)$ dan nilai signifikan $($ Sig. $t)$ sebesar 0,5080, berarti Sig t $(0,5080)>\alpha(0,05)$, sehingga Ho diterima dan Ha ditolak, artinya bahwa Leverage tidak berpengaruh signifikan terhadap Profitabilitas pada perusahaan pertambangan di Bursa Efek Indonesia (BEI). Koefisien regresi variabel Leverage $\left(\mathrm{X}_{4}\right)$ sebesar -0,011253, variabel Leverage berslope negatif artinya, ketika terjadi kenaikan Leverage perusahaan menyebabkan Profitabilitas perusahaan menurun. 
b) Uji F (uji bersama-sama)

Untuk mengetahui kelayakan model regresi digambarkan angka-angka dari tabel:

Tabel 10. Nilai Uji F

Effects Specification

Cross-section fixed (dummy variables)

Period fixed (dummy variables)

\begin{tabular}{llll}
\hline \hline R-squared & 0.851393 & Mean dependent var & 0.068533 \\
Adjusted R-squared & 0.766474 & S.D. dependent var & 0.055276 \\
S.E. of regression & 0.026712 & Akaike info criterion & -4.126306 \\
Sum squared resid & 0.019979 & Schwarz criterion & -3.443789 \\
Log likelihood & 109.8419 & Hannan-Quinn criter. & -3.871871 \\
F-statistic & 10.02600 & Durbin-Watson stat & 2.163102 \\
Prob(F-statistic) & 0.000000 & & \\
\hline \hline
\end{tabular}

$\begin{array}{lll}\text { Model } & \text { F } & \text { Prob(F-Statistic) } \\ \text { Regression } & 10,02600 & 0,0000\end{array}$

Sumber: data diolah, 2020

Berdasarkan Tabel 10, Jika F-hitung $>$ F-tabel, maka Ho ditolak dan Ha diterima dan sebaliknya F-hitung $<$ F-tabel, maka Ho diterima dan Ha ditolak. Dari hasil perhitungan, diperoleh angka F-hitung sebesar 10,02600 > F-tabel sebesar 2,61 sehingga Ho ditolak dan Ha diterima. Dengan demikian, model regresi tersebut sudah layak dan benar. Kesimpulannya adalah Working Capital Turnover $\left(\mathrm{X}_{1}\right)$, Firm Size $\left(\mathrm{X}_{2}\right)$, Likuiditas $\left(\mathrm{X}_{3}\right)$, Leverage $\left(\mathrm{X}_{4}\right)$ secara bersama-sama, positif dan signifikan memengaruhi profitabilitas (Y) pada perusahaan pertambangan di Bursa Efek Indonesia (BEI).

\subsection{Pembahasan dan Implikasi Penelitian}

1. Pengaruh Working Capital Turnover $\left(\mathrm{X}_{1}\right)$, Firm Size $\left(\mathrm{X}_{2}\right)$, Likuiditas $\left(\mathrm{X}_{3}\right)$, Leverage $\left(\mathrm{X}_{4}\right)$ secara parsial terhadap profitabilitas $(\mathrm{Y})$ pada perusahaan pertambangan di Bursa 
Efek Indonesia (BEI).

\section{a. Pengaruh Working Capital Turnover $\left(\mathrm{X}_{1}\right)$ terhadap Profitabilitas (Y)}

Hasil nilai t-hitung pengaruh Working Capital Turnover $\left(\mathrm{X}_{1}\right)$ terhadap Profitabilitas $(\mathrm{Y})$ sebesar 0,605407 dan nilai signifikansi (Probabilitas) sebesar 0,5498, berarti nilai thitung $(0.605407)<t_{\text {tabel }}(2,01290)$ dan nilai Signifikansi $(0,5498)>\alpha(0,05)$, sehingga Ho diterima dan Ha ditolak, artinya bahwa Working Capital Turnover tidak berpengaruh signifikan terhadap Profitabilitas pada perusahaan pertambangan di Bursa Efek Indonesia (BEI). Penelitian ini sejalan dengan yang dilakukan oleh Nugroho (2012). Penelitiannya Pengaruh Efisiensi Modal Kerja, Likuiditas, dan Solvabilitas terhadap Profitabilitas Studi Kasus PT. Telekomunikasi Indonesia, TBK. Hasil penelitian tersebut menunjukkan bahwa Secara parsial WCT, CR, dan Debt to Total Capital Asset tidak berpengaruh signifikan terhadap ROA.

b. Pengaruh Firm Size $\left(\mathrm{X}_{2}\right)$ secara parsial terhadap Profitabilitas $(\mathrm{Y})$

Nilai $t_{\text {hitung }}$ pengaruh Firm Size $\left(\mathrm{X}_{2}\right)$ terhadap Profitabilitas $(\mathrm{Y})$, adalah sebesar -0,067701; maka thitung $(-0,067701)>t_{\text {tabel }}(2,01290)$ dan nilai signifikan (Sig. t) sebesar 0,9465, berarti Sig t $(0,9465)>\alpha(0,05)$, sehingga Ho diterima dan Ha ditolak, artinya bahwa Firm Size tidak berpengaruh signifikan terhadap Profitabilitas pada perusahaan pertambangan di Bursa Efek Indonesia (BEI). Koefisien regresi variabel Firm Size $\left(\mathrm{X}_{2}\right)$ sebesar -0,000143, variabel Firm Size berslope negatif artinya, ketika terjadi kenaikan Firm Size perusahaan menyebabkan Profitabilitas perusahaan menurun. Sejalan dengan penelitian Rice (2014), mengenai Analisis Faktor Faktor yang Mempengaruhi Profitabilitas pada Perusahaan Kompas 100 yang Terdaftar di Bursa Efek Indonesia Periode 2008-2012. Secara parsial bahwa Ukuran Perusahaan tidak berpengaruh terhadap Profitabilitas.

\section{c. Pengaruh Likuiditas $\left(\mathrm{X}_{3}\right)$ secara parsial terhadap Profitabilitas $(\mathrm{Y})$}

Nilai $t_{\text {hitung }}$ pengaruh Likuiditas $\left(\mathrm{X}_{3}\right)$ terhadap Profitabilitas $(\mathrm{Y})$, adalah sebesar 2,827580; maka $t_{\text {hitung }}(2,827580)>t_{\text {tabel }}(2,01290)$ dan nilai signifikan (Sig. t) sebesar 0,0086, berarti Sig t $(0,0086)<\alpha(0,05)$, sehingga Ha diterima dan Ho ditolak, artinya bahwa Likuiditas berpengaruh yang signifikan terhadap Profitabilitas pada perusahaan pertambangan di Bursa Efek Indonesia (BEI). Koefisien regresi variabel Likuiditas $\left(\mathrm{X}_{3}\right)$ sebesar 0.036545 , variabel likuiditas berslope positif artinya, ketika terjadi kenaikan Likuiditas perusahaan menyebabkan Profitabilitas perusahaan meningkat. Sejalan dengan penelitian Menurut penelitian yang dilakukan oleh Debora (2014) yang menganalisis pengaruh likuiditas dan manajemen modal kerja terhadap profitabilitas perusahaan industri tekstil dan garmen yang terdaftar di Bursa Efek Indonesia Periode 2009 2012. Hasil pengujian menunjukkan bahwa secara parsial likuiditas berpengaruh terhadap profitabilitas

\section{d. Pengaruh Leverage $\left(\mathrm{X}_{4}\right)$ secara parsial terhadap Profitabilitas $(\mathrm{Y})$}

Nilai thitung pengaruh Leverage $\left(\mathrm{X}_{4}\right)$ terhadap Profitabilitas $(\mathrm{Y})$, adalah sebesar -0,670593; maka thitung $(-0,670593)>t_{\text {tabel }}(2,01290)$ dan nilai signifikan (Sig. t) sebesar 0,5080, berarti Sig t $(0,5080)>\alpha(0,05)$, sehingga Ho diterima dan Ha ditolak, artinya bahwa Leverage tidak berpengaruh signifikan terhadap Profitabilitas pada perusahaan pertambangan di Bursa Efek Indonesia (BEI). Koefisien regresi variabel Leverage $\left(\mathrm{X}_{4}\right)$ sebesar -0,011253, variabel Leverage berslope negatif artinya, ketika terjadi kenaikan Leverage perusahaan menyebabkan Profitabilitas perusahaan menurun. 
Sejalan dengan penelitian Agus Wibowo, Sri Wartini. 2016, Pengaruh Modal Kerja, Likuiditas dan Leverage terhadap Profitabilitas. Hasil analisis penelitiannya menunjukkan, dimana secara parsial likuiditas dan leverage tidak berpengaruh terhadap profitabilitas.

2. Pengaruh Working Capital Turnover $\left(\mathrm{X}_{1}\right)$, Firm Size $\left(\mathrm{X}_{2}\right)$, Likuiditas $\left(\mathrm{X}_{3}\right)$, Leverage $\left(\mathrm{X}_{4}\right)$ secara bersama-sama terhadap profitabilitas $(\mathrm{Y})$ pada perusahaan pertambangan di Bursa Efek Indonesia (BEI)

Pengaruh Working Capital Turnover $\left(\mathrm{X}_{1}\right)$, Firm Size $\left(\mathrm{X}_{2}\right)$, Likuiditas $\left(\mathrm{X}_{3}\right)$, Leverage $\left(\mathrm{X}_{4}\right)$ secara bersama-sama, positif dan signifikan memengaruhi profitabilitas (Y) pada perusahaan pertambangan di Bursa Efek Indonesia (BEI). hasil perhitungan, diperoleh angka F-hitung sebesar 10,02600 > F-tabel sebesar 2,61 sehingga Ho ditolak dan Ha diterima. Dengan demikian, model regresi tersebut sudah layak dan benar.

Sejalan dengan penelitian Novi Sagita A, Gede Adi Y, Ni Kadek S. 2015, Pengaruh Modal Kerja, Likuiditas, Aktivitas dan Ukuran Perusahaan terhadap Profitabilitas.Hasil penelitiannya menyatakan bahwa secara simultan modal kerja, likuiditas, aktivitas dan ukuran perusahaan berpengaruh signifikan terhadap profitabilitas pada perusahaan manufaktur yang terdaftar di bursa efek indonesia.

\section{Kesimpulan}

Peneliti memberikan kesimpulan pertama, Working Capital Turnover tidak berpengaruh signifikan terhadap Profitabilitas. Kedua, Firm Size tidak berpengaruh signifikan terhadap Profitabilitas. Ketiga, Likuiditas berpengaruh signifikan terhadap Profitabilitas. Keempat, Leverage tidak berpengaruh signifikan terhadap Profitabilitas pada perusahaan pertambangan di Bursa Efek Indonesia (BEI). Kelima, Working Capital Turnover, Firm Size, Likuiditas, Leverage secara bersama-sama, positif dan signifikan memengaruhi profitabilitas (Y) pada perusahaan pertambangan di Bursa Efek Indonesia (BEI).

\section{Saran}

Peneliti memberikan saran pertama, Perusahaan Pertambangan yang Terdaftar di Bursa Efek Indonesia harus menjaga kestabilan kinerja keuangannya, jika perlu meningkatkan working capital, firm size, likuiditas dan leverage agar bisa menjaga dan meningkatkan profitabilitas perusahaan. Kedua, Para pemegang saham Perusahaan Pertambangan yang Terdaftar di Bursa Efek Indonesia tidak secepatnya menarik sahamnya ketika terjadi penurunan harga saham, karena diharapakan tidak terlalu lama terjadi kestabilan dan meningkat kembali working capital, firm size, likuiditas dan leverage agar bisa menjaga sehingga meningkatkan profitabilitas perusahaan, dan harga saham kembali naik.

\section{Referensi (APA Style)}

Abdullah, M. Faisal, 2005. Dasar- Dasar Manajemen Keuangan, Edisi Kedua, Cetakan Kelima, Penerbitan Universitas Muhammadiyah, Malang.

Agus Wibowo, Sri Wartini. 2016. Efisiensi Modal Kerja, Likuiditas dan Leverage terhadap Profitabilitas pada Perusahaan Manufaktur di BEI.JDM_Jurnal Dinamika Manajemen. ISSN 2337-5434. Vol 3. No.1.Hal. 16 sd 28.

Ang, Robert. 2013. Buku Pintar Pasar Modal Indonesia (The Intelligent Guide To 
Indonesian Capital Market). Edisi Pertama : Jakarta.

Bringham dan Houston. 2012. Dasar-dasar Manajemen Keuangan. Edisi V. Jakarta : Salemba Empat.

Debora, 2014. "Pengaruh likuiditas dan manajemen modal kerja terhadap profitabilitas perusahan industry tekstil dan garmen yang terdaftar di Bursa Efek Indonesia Periode 2009-2012", Tesis, Magister Manajemen Fakultas Ekonomi, Universitas Sumatera Utara.

Erlina, 2008. Metodologi Penelitian dan Bisnis: Untuk Akuntansi dan MAnajemen. USU Press : Medan.

Garrison, Noreen, dan Brewer, 2007. Akuntansi Manajerial, Edisi 11. Diterjemahkan oleh : Nuri Hinduan dan Edward Tanujaya. Salemba Empat. Jakarta.

Ghozali, Imam. 2006. Aplikasi Analisis Multivariate Dengan Program SPSS. Cetakan Keempat. Semarang: Badan Penerbit Universitas Diponegoro.

Halim, Abdul. 2015. Manajemen Keuangan Bisnis: Konsep dan Aplikasinya. Jakarta: Mitra Wacana Media.

Jumingan. 2011. Analisis Laporan Keuangan. Jakarta: PT Bumi Aksara

Horne, James C. Van dan John M Wachowicz, Jr. 2012. Prinsip-prinsip Manajemen Keuangan (Edisi 13). Jakarta : Salemba Empat.

Kasmir, 2015. Analisis Laporan Keuangan, Rajawali Press, Jakarta. 2013. Analisi Laporan Keuangan. Rajawali Pers : Jakarta

Munawir, S. 2015. Analisis Laporan Keuangan. Edisi Keempat. Yogyakarta: Liberty Murti, Sumarni, dan Salamah Wahyuni, 2006. Metodologi Penelitian Bisnis, CV. Andi Offset, Yogyakarta

Novi Sagita A, Gede Adi Y, Ni Kadek S. 2015. Pengaruh Modal Kerja, Likuiditas, Aktivitas dan Ukuran Perusahaan Terhadap Profitabilitas Pada Perusahaan Manufaktur Yang Terdaftar Di Bursa Efek Indonesia. Vol 3 No. 1. Undiksha Hal 11-19.

Nugroho, 2012. "Pengaruh Efisiensi Modal Kerja, Likuiditas, dan Solvabilitas terhadap Profitabilitas pada industry farmasi yang terdaftar di Bursa Efek Industri (BEI)", Tesis Magister Akuntansi, Fakultas Ekonomi, Universitas Sumatera Utara.

Martono, Agus Harjito. 2011. Manajemen Perkreditan. Jakarta : Bumi Aksara.

Ramadhan, Fajrul. 2017. "Pengaruh Manajemen Modal Kerja, Likuiditas, Leverage dan Corporate Governance Terhadap Profitabilitas Pada Perushaaan Manufaktur yang Terdaftar di Bursa Efek Indonesia." Tesis, Fakultas Ekonomi Universitas Sumatera Utara.

Rice, 2014. "Faktor-faktor yang Mempengaruhi Profitabilitas pada Perusahaan Kompas 100 yang Terdaftar di Bursa Efek Indonesia Periode 2008-2012", Jurnal Wira Ekonomi Mikroskil.

Sadalia, Isfenti, 2010. Manajemen Keuangan, USU Press, Medan.

Sangadji, E.M. dan Sopiah, 2010. Metodologi Penelitian (Pendekatan Praktis dalam Penelitian), Yogyakarta 
Sartono , R. Agus, 2014. Manajemen Keuangan Teori dan Aplikasi, Edisi 4, BPFE, Yogyakarta.

Sawir, Agnes, 2016. Analisis Kinerja Keuangan dan Perencanaan Keuangan Perusahaan. Jakarta: PT. Gramedia Pustaka Utama.

Sofyan Badri. 2012. Metode Statistika. Yogyakarta : Penerbit Ombak.

Sumarni, Murti dan Salamah Wahyuni. 2006. Metodologi Penelitian Bisnis. Edisi I : Yogyakarta.

Suyanto, K.D. dan Supramono. (2012). Likuiditas, leverage, komisaris independen, dan manajemen laba terhadap agresivitas pajak perusahaan. Jurnal Keuangan Dan Perbankan, Vol.16, No.2 Mei 2012, Hal: 167-177.

Daniel. 2012. Kemampuan Rasio Keuangan dan Ukuran Perusahaan dalam Memprediksi Kinerja Keuangan. Jurnal Widya Manajemen \& Akuntansi. Vol 2, No 1. 2012.

Wild, Jhon. J, K. R. Subramanyam, 2010, Analisis laporan keuangan, Salemba Empat, Jakarta. 